\title{
FULL FAITH AND CREDIT-A SUGGESTED APPROACH TO THE PROBLEM OF RECOGNITION OF FOREIGN CORPORATIONS
}

\author{
Harold Wright Holt $\dot{\uparrow}$
}

\section{INTRODUCTION}

A corporation formed under a general statute of state $X$ seeks to conduct in state $Y$ an intrastate business ${ }^{1}$ of a kind which $Y$ permits corporations to carry on if created under its own general corporation statute. By this statute requiring corporations wishing to carry on intrastate business of that kind to be associations of its own creation, $Y$ has "excluded" foreign corporations." Our inquiry is: Can $Y$ so secure a monopoly of local business ${ }^{3}$ to its own corporations?

Even when no claim to immunity from unlimited personal liability is involved, $Y$ might perhaps reserve the use or exploitation of certain of its natural resources to its own citizens,-e. g., the privilege of planting oysters in its tidal waters. ${ }^{4}$ Perhaps it could reserve to its own citizens even the privilege of disposing in trade of the oysters there raised. However, apart from a few exceptional cases a state may not under the privileges and immunities clause exclude citizens of other states from doing within its borders a local business of a kind which it permits its own citizens to do. ${ }^{5}$ Nor can it exclude citizens of other states from doing through the agency of other human beings local business of a kind which it permits or would permit its own citizens to do through the same persons as agents. ${ }^{B}$

When, however, the benefit of limited liability is desired, $Y$ has decreed that it is available only by virtue of the local corporation laws. Although $Y$ holds that the use of the corporate form of organization is dictated by the needs of modern commercial enterprise and permits an indefinite number of domestic corporations to carry on this particu-

† A. B., I917, Dartmouth College; LL. B., I920, S. J. D., I928, Harvard University; member of Illinois and American Bars; Professor of Law at University of Illinois; author of RestatMent, ConTRACrs, IlL. ANNOT. (1936); contributor to various legal periodicals.

I. I. e., "intrastate" in that no tax or regulation imposed by $Y$ upon the corporation because of its carrying on of the business would violate the commerce clause.

2. Unless otherwise stated a "foreign corporation" is a corporation created under the laws of a state of the United States other than the one whose statute is challenged as to constitutionality.

3. "Local business" is a synonym for "intrastate business".

4. McCready v. Virginia, 94 U. S. 391 (1877).

5. See Slaughterhouse Cases, i6 Wall. 36, Ior (U. S. I873); Ward v. Maryland, I2 Wall. 4I8, 430 (U. S. I870).

6. See Flexner v. Farson, 248 U. S. 289 (I918). 
lar type of local business, ${ }^{7}$ its liberal policy does not extend to corporations formed under the laws of another state.

Nor does the privileges and immunities clause of the Constitution require any different policy with respect to foreign corporations. One could forcibly argue that that clause should not be wholly inapplicable to corporations-that with certain exceptions and subject to certain limitations a corporation created under the statute of $X$ could claim the protection of that clause as against the claim of $Y$ of a power to exclude it from carrying on a local business in $Y{ }^{8}$ If all the American commonwealths pursued in regard to foreign corporations the policy herein ascribed to $Y$, many trading and manufacturing businesses now carried on in several states by one corporation would have to be conducted at greater expense and with less efficiency by several corporations. But however plausible the argument may be for extending the benefit of the privileges and immunities clause to corporations, such an argument is of little avail in the light of what the Court has repeatedly said. Over seventy years ago one member spoke as follows:

"If the right asserted of the foreign corporation, when composed of citizens of one State, to transact business in other States were even restricted to such business as corporations of those States were authorized to transact, it would still follow that those States would be unable to limit the number of corporations doing business therein. They could not charter a company for any purpose, however restricted, without at once opening the door to a flood of corporations from other States to engage in the same pursuits. They could not repel an intruding corporation, except on the condition of refusing incorporation for a similar purpose to their ozen citizens; and yet it might be of the highest public interest that the number of corporations in the State should be limited; that they should be required to give publicity to their transactions; to submit their affairs to proper examination; to be subject to forfeiture of their corporate rights in case of mismanagement, and that their officers should be held to a strict accountability for the manner in which the business of the corporations is managed, and be liable to summary removal." 9

Implicit in this language is a feeling that public interest may require a state to restrict to a definite number of corporations the privilege of doing a kind of intrastate business with limited liability under the

7. Y's grant of a corporate charter is not "a bestowal of gracious favor by an act of high prerogative", Powell, Indirect Encroachment on Federal Authority by the Taxing Powers of the States (I9I9) 32 HARv. L. REv. 634, 653.

8. See Henderson, The Position of Foreign Corporations in Anerican Constitutional Law in 2 HARVARD STUDIES IN JURISPRUDENCE (I918) 178 et seq.

9. Mr. Justice Field in Paul v. Virginia, 8 Wall. I68, I82 (U. S. I869) (Italics added). See also dissenting opinion of $\mathrm{Mr}$. Justice Black in Connecticut General Life Ins. Co. v. Johnson, 303 U. S. 77, 83 (I938). Cf. Ins. Co. v. Morse, 20 Wall. 445,456 (U. S. 1874 ). 
corporate form of organization. It may serve the public interest of a state to limit the corporations that can carry on intrastate business of a particular kind to such as secure a permit from some administrative board. A state may, moreover, allow only domestic corporations to secure such permission. It is no violation of the Constitution, therefore, for a state to limit the privilege of carrying on an intrastate express business under the corporate form of organization to domestic corporations. ${ }^{10}$ A state may refuse to allow a foreign corporation to engage in an intrastate business of a kind not permitted a domestic corporation. ${ }^{11}$ And a foreign corporation has no constitutional privilege of conducting an intrastate business that is illegal, even if within the state of incorporation business of that kind is legal. ${ }^{\mathbf{1 2}}$ The public interest that is served by forbidding a domestic corporation to conduct a certain type of local business justifies extension of the prohibition to foreign corporations. The protection of the peculiar public interests that make some businesses subject to a special type of regulation-the so-called public utilities-may also reasonably justify the limitation of the privilege of conducting local business of such kinds to domestic corporations. But it does not follow that under the Constitution a state may allow any number of domestic corporations to engage in an intrastate business of a particular kind and exclude all foreign corporations from doing that kind of local business.

At present it is not difficult to get the privilege of carrying on most manufacturing or trading businesses under the protection of a corporate charter. The privilege of incorporation under a liberal type of statute ${ }^{13}$ may be open not only to citizens and residents of the state, but to non-residents as well. Nor is there a limit to the number of corporations that may be formed. Quite the contrary-the greater the number, the greater the revenue obtained from fees. If a state tolerates the carrying on of a large variety of trading and manufacturing enterprises within its borders by an indefinite number of domestic corporations, can it claim that any interest of its own requires the exclusion of foreign corporations from all such enterprises? It is difficult to believe that any such interest exists. Any foreign corporation permitted to engage in intrastate business will be subject to the jurisdiction of the state courts in all actions brought on causes arising from the conduct of such business. ${ }^{14}$ Such foreign corporation can also be compelled to file information each year as to its financial condition. ${ }^{\mathbf{1 5}}$

Io. Railway Express Agency, Inc. v. Virginia, 282 U. S. 440 (I93I).

II. Crescent Cotton Oil Co. v. Mississippi, 257 U. S. I29 (1921).

I2. See Lottery Case, I88 U. S. 321, 357 (1903).

I3. E. g., ILI. Rev. Stat. (1939) c. 32, \$ 157. I et seq.

14. See Old Wayne Mut. Life Ass'n v. McDonough, 204 U. S. 8 (1907), cited in Simon v. Southern Ry., 236 U. S. I15, 130-132 (1915).

I5. E. g., Ill. Rev. STAT. (I939) c. 32, \$§ I57.II5, I57.1 I6. 
For false statements in a certificate or other statement of information the persons responsible can be held liable civilly ${ }^{16}$ or criminally. ${ }^{17}$ The courts of the state upon application of the proper parties could prevent a mismanagement of the intrastate business of the corporation. ${ }^{18}$ The foreign corporation can be required to contribute in taxes or fees toward the maintenance of the state government. ${ }^{19}$ In short the fears of Mr. Justice Field in Paul v. Virginia ${ }^{20}$ as to the evils of extending to foreign corporations the same or similar liberal privileges in the carrying on of intrastate business as are extended to domestic corporations seem groundless.

The theory of the power of a state to "exclude" a foreign corporation from participation in intrastate business owes a large part of its development to statements of Chief Justice Taney in Bank of Augusta $v$. Earle ${ }^{21}$ who spoke in language that is an odd medley of thought as to the nature of a corporation and as to the possibility of effective corporate action outside the state of incorporation. At the time he spoke freedom of incorporation was not yet widespread. Taney had come to maturity while the use in this country of the corporate form of business enterprise was for the most part limited to turnpike and canal companies, with activities confined to well-defined territories,-corporations of a kind now roughly described as "public utilities". Corporations had rarely been formed to engage in manufacturing or the sale of goods or services. ${ }^{22}$ Traces of Taney's anthropomorphism still survive, albeit in more subtle form. ${ }^{23}$

Consider what actually happens. Certain documents are filed in state $X$ and certain fees paid. An official delivers a certificate which says that $A, B$ and $C$ with others may engage in certain activities for a profit-making purpose with their liability limited to their contributions to capital. The documents are filed, the fees paid and the certificate granted pursuant to a statute of $X$. The corporation is thus formed by virtue of a statute. The members of the corporation (the shareholders) secure the privilege of profiting from the conduct of a business enterprise at the risk of only a limited liability because the statute of $X$ so enacts. Certainly the members of the corporation so long as it engages in business in $X$ in a lawful manner and in compliance with the cor-

16. 2 MASS. GEN. LAwS (1932) c. I8I, \$\$ I4, I7.

I7. $I d$., c. I $55, \$ \S 48,49$.

18. E. g. by receivership proceedings; see Williamson v. Missouri-Kansas Pipe Line Co., $56 \mathrm{~F}$. (2d) 503 (C. C. A. 7 th, 1932); Restatement, Conflict of Laws (I934) \$\$ 525-527; Kearns, Interstate Receivership Practice (1934) 28 ILL. L. Rev. 752. Cf. Rogers v. Guaranty Trust Co., 288 U. S. 123 (r932).

19. See discussion under Part II.

20. 8 Wall. 168 , I82 (U. S. I868).

21. I3 Pet. 519, 588 (U. S. I839).

22. Williston, The History of the Laze of Business Corporations Before I800, 3

Select Essays in Anglo-A merican Legal History (Ig09) I95, 234-235.

23. E. g. Atlantic Refining Co. v. Virginia, 302 U. S. 22, 26 (I937). 
poration statutes of the state will have the benefit of the limited liability conferred by the statute. Now, to what extent does the full faith and credit clause require the courts of $Y$ to limit the liability of members of that corporation in the manner directed by the statute of $X$ ?

There is no need to stress that incorporation of the ordinary type of commercial enterprise has ceased to be a matter of special legislative grant and has come to be a privilege obtainable on compliance with some general statute. Nor is it necessary to state the development of - rules, principles and concepts relative to the legal relations of a foreign corporation. In the development of that jurisprudence the interstate commerce clause and the Fourteenth Amendment have had dominant roles. The privileges and immunities clause has availed foreign corporations nothing. Little attention has been paid to the full faith and credit clause. But in view of recent decisions which show that that provision is not wholly inapplicable to the statutes of a sister state, even though Congress fails to provide what effect shall be given to authenticated public acts, ${ }^{24}$ and because incorporation of the ordinary trading or manufacturing business is now under a general statute, rather than by special act, may it not be that a new approach should be taken to some of the problems concerned with recognition of foreign corporations? May it not be that a state has to allow a foreign corporation to do a local business within its borders unless it shows some interest in "exclusion"? May it not be that it is a denial of full faith and credit to the statute of a sister state to allow only domestic corporations to carry on a local business?

\section{Taxation of Foreign Corporations}

One important group of cases involving the theory of the power of a state to "exclude" a foreign corporation from a local business consists of those challenging the constitutionality of state taxation. To be sure, even if a state has under the Constitution absolute power to prevent a foreign corporation from doing a local business within its territory, it does not necessarily follow that the state may exact any fee it chooses in return for the grant to such corporation of the privilege of engaging in such business. Power to exclude would not necessarily give the state power to condition its grant of the privilege in any way it saw fit. ${ }^{25}$ Yet in Horn Silver Mining Co. v. New York it was said:

24. See Notes (I935) 35 CoL. L. REv. 75I ; (1937) 37 CoL. L. REv. 485; (I937) 50 Harv. L. Rev. 520; (I935) 45 Yale L. J. 339.

25. See discussion of "unconstitutional conditions" in Henderson, note 8 supra at c. viii; Hale, Unconstitutional Conditions and Constitutional Rights (1935) 35 CoL. L. REv. 32r ; Merrill, Unconstitutional Conditions (I929) 77 U. OF PA. L. REV. 879; Sharp, Movement in Supreme Court Adjudication-A Study of Modified and Overruled Decisions (1933) 46 HARv. L. REv. 593, 629-630. Illustrative of a former trend 
"Having the absolute pozerer of exchuding the foreign corporation the State may, of course, impose such conditions upon permitting the corporation to do business within its limits as it may judge expedient; and it may make the grant or privilege dependent upon the payment of a specific license tax, or a sum proportioned to the amount of its capital. No individual member of the corporation, or the corporation itself, can call in question the validity of any exaction which the State may require for the grant of its privileges." 26

In that case objections to a tax levied by New York upon a mining corporation of Utah were based on the grounds that the tax statute violated principles of equality and uniformity and denied equal protection of the laws. The objections were disposed of by the assertion:

"It does not lie in any foreign corporation to complain that it is subjected to the same law with the domestic corporation." 27

This equality of treatment of foreign and domestic corporations is important. The tax levied upon the corporation was neither more nor less than that which New York would have levied upon a domestic corporation doing the same kind and amount of business and possessing the same kind and amount of property with the same location.

It may well be that later decisions overrule the Horn Silver Mining Co. case insofar as it stands for the proposition that the Constitution allows a state to exact of a foreign corporation any fee or tax it sees fit to impose as a return for permitting such corporation to engage in a local business within the state. ${ }^{28}$ But the case still has importance in that it did not hold that New York by means of its taxing power could exclude foreign corporations from the field of intrastate business and allow only corporations of its own creation to graze therein.

Once a foreign corporation has qualified under the statutes of $Y$ for the transaction of intrastate business therein, is the corporation entitied to the benefit of the equal-protection-of-the-laws clause of the Fourteenth Amendment so far as state taxation in $Y$ is concerned? E. g., a corporation incorporated in $X$ qualifies to engage in intrastate business in $Y$. After it has commenced to carry on such a business, $Y$

contrary to the position stated by the writer see Allen v. Pullman's Palace Car Co. I9I U. S. I7I (1903); Pullman Co. v. Adams, 189 U. S. 420 (1903). Cf. Maine v. Grand Trunk Ry., I42 U. S. 2I7 (I89I) and explanation thereof in Galveston, H. \& S. A. Ry. v. Texas, 210 U: S. 217 (1908). added).

26. Horn Silver Mining Co. v. New York, 143 U. S. 305, 315 (I892) (Italics

27. Ibid.

28. See Henderson, note 8 supra at c. vi; Powell, note 7 supra at $6 \mathrm{r}_{3}$ and 759 , and (r919) 32 HaRv. L. Rev. 634 at $649-650$; but cf. Note (1940) 53 Harv. L. REv. 672. 
passes a statute imposing upon this foreign corporation a tax to which domestic corporations engaged in similar business within the state are not subject. The tax burdens of foreign corporations doing intrastate business in state $Y$ are increased, but those of domestic corporations carrying on the same kind of business are not. Would such legislation violate the equal-protection-of-the-laws clause?

Southern Ry. v. Greene, ${ }^{29}$ supplemented by Hanover Fire Insurance Co. v. Harding ${ }^{30}$ shows that in some cases it would. And these cases have considerable significance upon our problem. Suppose our hypothetical corporation were to be admitted to do an intrastate business in $Y$ before that state passed a statute that the only corporations it would thereafter permit to carry on that kind of local business in $Y$ would be those of its own creation. As applied to our corporation such a statute would seem to violate the equal-protection-of-the-laws clause. True, the investors in that corporation (the stockholders) might cause a domestic corporation to be formed under the laws of $Y$ to take over the business. So a domestic (Alabama) corporation could have been formed in Southern Ry. v. Greene. Had the Supreme Court handed down a contrary decision, the probability is that an Alabama corporation would have been organized to take over and operate the properties in that state of the Southern Railway Company. ${ }^{31}$ So also an Illinois corporation could have been formed, had a contrary decision been rendered in Hanover Fire Insurance Co. v. Harding, to take over the business in Illinois of the Hanover Fire Insurance Company, with its stock owned or controlled by that company. But the possibility of organizing a subsidiary domestic corporation in the taxing state is not an effective answer to the contentions of the complainant foreign corporations in those cases. Those decisions rest on the extension of the equal-protection-of-the-laws clause to a foreign corporation doing a local business in the state.

In Southern Ry. v. Greene the corporation was engaged in both interstate and intrastate transportation, and there was some indication that the doctrine of that case was to be limited to public service or utility corporations. ${ }^{32}$ In fact the court did state that its decision was in a large part dictated by the holding in Western Union Telegraph Co. v. Kansas ${ }^{33}$ in which the carrying on in Kansas by a foreign corporation of the business of both interstate and intrastate transmission of information was an important factor. However, a foreign corporation doing only an intrastate business is likewise entitled to equal protection

29. 216 U. S. 400 (1910).

30. 272 U. S. 494 (I926).

31. See Henderson, note 8 sipra at I53-1 54 .

32. White Co. v. Commonwealth, 2 I8 Mass. 558, 579-580, 106 N. E. 310, 319 (I9I4), cert. granted, 246 U. S. I47, I56 (I918).

33. 216 U. S. I (IgIO). 
of the laws. ${ }^{34}$ Nor is the fact that the Southern Railway Company was engaged in transportation to be stressed. ${ }^{35}$ In Hanover Fire Insurance Co. v. Harding a foreign corporation was carrying on an insurance business and no interstate commerce was involved. ${ }^{36}$ The case indicates that the doctrine of the Greene case is not limited to foreign corporations that have acquired "permanent and valuable" property within the taxing state nor to public utility corporations engaged in transportation. Seemingly any foreign corporation that (I) has once lawfully secured permission to do business in a state, (2) has pursuant thereto done business therein and (3) has built up an expectancy of continued business therein ("goodwill") is entitled to the benefit of the equal-protection-of-the-laws clause as applied in Southern Ry. v. Greene. If any permanent investment is needed, the presence of "large numbers of records" concerning the business will suffice. Under present day business methods no corporation need fear that it will be unable to satisfy this requirement! Perhaps it is essential that the business be "large and profitable". Whether it is or not, one thing is certain-if the business is not "profitable", the foreign corporation will eventually come to consider its constitutional privileges as of only academic interest.

There still remains the problem suggested by, but not directly presented in, Hanover Fire Insurance Co. v. Harding: Could $Y$ make a promise of future compliance with the tax statute a condition precedent to renewal of the license? The recent case of Atlantic Refining Co. $v$. Virginia ${ }^{37}$ has some bearing.

The Atlantic Refining Company, a Pennsylvania corporation, had before 1930 transacted interstate commerce in Virginia. In that year it applied to the Virginia Corporation Commission for a certificate of authority to engage in intrastate business. It had never previously done any local business in the state, but had had its product marketed locally through two other duly qualified foreign corporations. The Atlantic Refining Company had never had any property or place of business in Virginia. The certificate was granted, but according to statute payment of $\$ 5000$ as a fee was exacted. The corporation paid under protest, sued for a refund and failed to recover. The highest state court affirmed the denial and its judgment was affirmed by the Supreme Court of the United States.

34. Power Manufacturing Co. v. Saunders, 274 U. S. 490 (1927). Even if the foreign corporation is not authorized to do business within the state, the equal-protection-of-the-laws clause prevents the state from arbitrarily discriminating against it when it seeks to sue to recover tangible property taken into the state without its knowledge or consent: Kentucky Finance Corp. v. Paramount Auto Exchange Corp., 262 U. S. 544 (1923).

35. 216 U. S. 400,412 (I9I0).

36. See N. Y. Life Ins. Co. v. Deer Lodge County, 23I U. S. 495 (1913).

37. 302 U. S. 22 (1937). 
The Virginia statute ${ }^{38}$ fixed the fee for a corporation with an authorized capital stock of $\$ 50,000$ or less at $\$ 30$ and for a corporation with an authorized capital stock in excess of $\$ 90,000,000$ at the sum of $\$ 5000$. For a corporation with an authorized capital between these two extremes the amount of the fee was determined according to a scale not graduated in proportion to the amount of authorized capital. At the time of its application the Atlantic Refining Company had an issued capital of $\$ 67,049,500$, an authorized capital of $\$ 100,000,000$ and net assets in excess of $\$ 132,000,000$.

The Court, speaking through Mr. Justice Brandeis, did not decisively state whether Virginia could have "excluded" the corporation from intrastate business in that Commonwealth. In regard to doing such business the statement was made that,

"Whether the privilege shall be granted to a foreign corporation is a matter of state policy. Virginia might refuse to grant the privilege for any business, or might grant the privilege for some kinds of business and deny it to others. It might grant the privilege to all corporations with small capital while denying the privilege to those whose capital or resources are large. It might grant the privilege without exacting compensation; or it could insist upon a substantial payment as a means of raising revenue." 39

On that premise-and in accord with the distinction drawn in Hanover Fire Insurance Co. v. Harding ${ }^{40}$ between the powers of a state over entrance fees demanded of foreign corporations for the grant of authority to transact intrastate business and taxes levied upon foreign corporations after they have qualified for, and engaged in, the transaction of such business-the court might have held that the measure of the fee was in the discretion of Virginia and that any inequality as between foreign corporations and domestic corporations in that regard did not fall within the prohibitions of the due process clause or of the equal-protection-of-the-laws clause of the Fourteenth Amendment.

However, the Court was willing to consider whether the exaction of the sum of $\$ 5000$ violated any constitutional right of the Atlantic Refining Company. It concluded that

"Even if the Federal Constitution conferred upon every foreign corporation the right to enter any State and carry on there a local business upon paying a reasonable fee, there is nothing in the record to show that the $\$ 5,000$ charged is more than reasonable compensation for the privilege granted." 41

38. VA. TAX CODE (Michie, I936) §207.

39. 302 U. S. 22,26 (1937).

40. 272 U. S. $494,510,5$ II (1926).

4I. 302 U. S. 22, 27 (1937). 
The corporation contended that measuring the entrance fee solely by the authorized capital deprived it of property without due process of law because the amount was determined by reference to property beyond the taxing power of Virginia. The Court answered with the statement that the fee was paid for a privilege granted.

As to the contention that the statute denied equal protection of the laws it was said:

"Even if a corporation which has not yet been admitted to do business were in a position to complain that the State denies it equal protection, there is here no basis for a claim of discrimination. Every foreign corporation with an authorized capital exceeding ninety million dollars which seeks admission to do an intrastate business is, and has been since IgIO, required to pay the same entrance fee." 42

But perhaps the most significance is to be attached to the following:

"Nor is there any discrimination between foreign corporations and domestic of which the company may complain. While the charter fees of domestic corporations are smaller than the entrance fees of foreign corporations, Virginia levies upon foreign corporations, after admission, less in taxes than it does upon domestic corporations. A domestic corporation with an authorized capital of $\$ 100,000,000$ is required to pay a charter fee of only $\$ 600$; but it must pay each year a franchise tax of $\$ 8,850$. A foreign corporation of that authorized capital is required to pay an entrance fee of $\$ 5,000$, but pays no franchise tax whatever." 43

One factor, then, in determining the "reasonableness" of the Virginia fee is the fact that the amount is not out of line with the amount exacted as fees and taxes of domestic corporations of similar capitalization. No indication is given as to where the line is to be marked out between "reasonableness" and "arbitrariness"; but one cannot avoid feeling after a perusal of the opinion that somewhere such a line is to be drawn.

The writer will refrain from a detailed discussion of tax decisions, but will content himself with pointing out that the powers of a state in regard to the exaction of a fee from a foreign corporation for granting the privilege of doing a local business are not as broad as its powers in regard to charging a domestic corporation for the same privilege. The discrimination is not against the foreign corporation, but in favor of it. True, a state may have as broad powers in exaction of a fee or tax for allowing a foreign corporation to engage only in a purely intrastate business as it has in regard to charging a domestic corporation for the 
same privilege. ${ }^{44}$ A state may measure the charter fee of a domestic corporation by a percentage of the total authorized capital stock without regard to any maximum and may graduate the same in direct proportion to the amount of total authorized capital. ${ }^{45}$ The license fee or tax a state may levy upon a foreign corporation for the privilege of doing both interstate and intrastate business cannot be so measured. ${ }^{46}$ Clearly the Atlantic Refining Company was not put into the position of complying in the future with a revenue statute discriminating against it in favor of domestic corporations.

The decision does not mean that Virginia could have excluded the corporation entirely. There are, as has been said, statements that it could, but these, it is submitted, are not to be taken literally in view of the assumption to the contrary made by the court for the sake of argument and the pains taken to show that the fee was not unreasonable in the light of the charges Virginia exacted of similar domestic corporations. As has been pointed out, even if a state does have power to "exclude" a foreign corporation from a local business, it does not necessarily have power to condition in any way it sees fit its grant of a license to engage in such business. However, the amount of a fee charged for granting such privilege would not, in itself, make the exaction of the fee an "unconstitutional condition". The decision does not warrant any conclusion that the state could give a monopoly of local business to domestic corporations. In this respect the case is on a par with Horn Silver Mining Co. v. New York. ${ }^{47}$

If Virginia had the unrestrained power to "exclude" the foreign corporation from local business, here was a good case. The company had no property in the state. It had done no local business there. It could have kept on with the subsidiary corporations. However, to hold that Virginia could exact an entrance fee of any amount it sees fit to charge would be to open the door to allowing each state in which the Atlantic Refining Company does business to force the local business of the company in such state to be handed over to a local domestic corporation, with the consequent inefficiencies and losses already suggested.

The truth is that the theory of the power of a state to "exclude" a foreign corporation from intrastate business has now little, if any, use in the determination of the constitutionality of a fee or tax demanded for granting or continuing the privilege of doing such business. Once the privilege has been granted, the Fourteenth Amendment prevents the state from discriminating against the corporation in taxation in favor of domestic corporations doing the same kind of business. It

44. Ford Motor Co. v. Beauchamp, 308 U. S. $33 \mathrm{I}$ (1939).

45. Kansas City, M. \& B. R. R. v. Stiles, 242 U. S. III (IgI6).

46. See Note (I938) 5I HaRv. L. REv. 508.

47. See p. 457 supra. 
seems probable, furthermore, that a state cannot "exclude" a foreign corporation from a local business if the corporation is engaged or proposes to engage in an interstate business which, for efficient and economical operation, requires the doing in association of a local business of that particular type. ${ }^{48}$ No reasonable inference can be drawn from the Atlantic Refining Company case or from Ford Motor Co. $v$. Beauchamp ${ }^{49}$ that a state can "exclude" a foreign corporation from a local business which it permits as many domestic corporations to carry on as there are groups of investors willing to incorporate under its statute dealing with the formation of business corporations.

But a foreign corporation seeking a permit to do local business within a state is not yet a "person" within the "jurisdiction" entitled to "equal protection of the laws". Any claim by it of constitutional right to do a local business must rest on some other part of the Constitution.

\section{Imposition of Additional Liabilities Upon Members of FOREIGN CORPORATIONS}

Through the use of the corporate form of organization investors in a commercial enterprise may secure the benefit of limited liability. The assets of the corporation may not suffice for the payment of its obligations, but ordinarily once a stockholder has paid the full amount due upon his stock subscription, he is discharged from further liability to the corporation or its creditors. In certain cases stockholders may be liable for an additional amount, but seldom do they incur unlimited liability for corporation debts. Were there not limited liability there would be slight incentive for contributors of capital to use the corporate form of business organization. ${ }^{50}$ What is the duty of other states towards enforcing such limited liability? If they are under a duty to enforce it, the conclusion can be reasonably drawn that such other states are compelled to apply the full faith and credit clause to that part of the incorporation statute of the sister state the operation of which distinguishes the corporate form of business organization from other forms of commercial associations.

Full faith and credit may also require a state to allow enforcement in its courts of the liability imposed upon stockholders in a foreign corporation by a statute of the state of incorporation. Whether the duty to give such full faith and credit exists depends upon whether the statute is so drawn that courts in other states can enforce liabilities

48. See Powell, note 7 supra at 608.

49. 308 U. S. 33I (1939).

50. Warren, Corporate Advantages Without Incorporation (ig29) 25-26. 
arising under it. ${ }^{51}$ And, carrying the question still further, what are the powers of a state as to the imposition of liabilities upon stockholders in a foreign corporation which are not imposed by the law of the state of incorporation?

Suppose $Y$ has a statute that imposes personal and individual liability upon stockholders of all corporations, domestic and foreign, for obligations of their respective companies wherever incurred. The statute allows any creditor of any corporation to recover judgment against any stockholder in the debtor company for such a proportion of the indebtedness as the amount of stock owned at the time the obligation is incurred bears to the total of the subscribed shares. Assume, further, a case where (I) the plaintiff, a resident of state $M$, is a bona fide creditor of a corporation formed in $X$ solely to do business in that state, (2) the plaintiff's claim arises from non-performance of a contract made with the corporation in $X$ under which all performance was to have taken place there, and (3) defendant, a stockholder, is a resident of $Z$, but subject to personal service of process in $Y$. No one would be a Cassandra who predicted that, if the court of $Y$ held the statute applicable to the facts just set forth, the Supreme Court would hold that it violated due process in that its passage was beyond the legislative competence of the state. ${ }^{52}$ Why should $Y$ be allowed to enforce the statute in the case put? What interests of its own would such enforcement serve? The parties are neither citizens nor residents of $Y$. The corporation has not done business therein. It has incurred no debt or other obligation in $Y$.

Still, under some circumstances $Y$ might make a stockholder in a foreign corporation personally liable for a corporation obligation. By statute California formerly did impose upon a stockholder of a domestic corporation or of a foreign corporation doing business in the state individual and personal liability for such proportion of any of its debts and liabilities as the amount of stock owned at the time such obligation was incurred bore to the whole of the subscribed stock. ${ }^{53}$

In Pinney $v$. Nelson ${ }^{54}$ a California court had held California citizens and residents as stockholders in a Colorado corporation liable for their proportionate shares of a debt incurred by the corporation under contracts made, executed and performable in California. The

5I. See Broderick v. Rosner, 294 U. S. 629 (1935); Abbot, Confict of Lawes and the Enforcement of the Statutory Liability of Stockholders in a Foreign Corporation (1909) 23 HARv. L. REv. 37; Langmaid, The Full Faith and Credit Required for Public Acts (1929) 24 ILI. L. REv. 383, 393-395.

52. Cf. Mutual Life Ins. Co. of N. Y. v. Liebing, 259 U. S. 209 (1922) ; N. Y. Life Ins. Co. v. Dodge, 246 U. S. 357 (I918); N. Y. Life Ins. Co. v. Head, 234 U S I49 (I913)

53. CaL. Const. I879, Art. I2, \$\$ 3, 15 (now repealed); CaL. Civ. Code (Deering, I886) $\$ 322$ [repealed by CAL. Crv. CODE (Deering, I93I) § 322].

54. I83 U. S. I44 (IgOI). 
articles of incorporation stated that the corporation was created to carry on part of its business outside of Colorado and that the principal plant and operations outside of that state should be in California. Seemingly Colorado law imposed no liability for corporate debts upon stockholders. The Federal Supreme Court held that enforcement of the statute of California did not violate the due process clause or the equalprotection-of-the-laws clause of the Fourteenth Amendment.

In Thomas $v$. Matthiessen ${ }^{55}$ a California citizen sued in New York $^{56}$ to enforce against a resident of that state, a stockholder in an Arizona corporation formed to erect and run a hotel in California, the liability the defendant was alleged to have incurred under the statute of California for the payment of a part of the amount due upon two notes given by the corporation in California for money lent. The corporation had qualified to do business in California, had built the hotel and had become insolvent. Under Arizona law the stockholders were exempt from personal liability for debts of the corporation. ${ }^{57}$ Furthermore, at the time the defendant subscribed for his stock he had made a written agreement with the corporation whereunder the latter had promised that he should be exempt from personal liability. The trial court gave judgment for the defendant, the Circuit Court of Appeals affirmed, but on certiorari the Supreme Court reversed.

Neither of these cases upholds the constitutionality of a statute imposing individual liability upon all stockholders in any corporation for all obligations of such corporation. In both, the stockholders were charged with liability for obligations under contracts said to have been "made" and to have called for performance in California. In Thomas v. Matthiessen the notes were executed and delivered in that state and presumably the money lent upon them was spent there. In Pinney $v$. Nelson the court refused to discuss whether the stockholders could be charged with liability under the statute for obligations contracted in the course of business transacted in Colorado. The court refused also to consider whether the defendant would have been held liable in the absence of the provision in the charter specifically naming California as a state in which the corporate business was to be conducted. In the Thomas case $\mathrm{Mr}$. Justice Holmes questions whether the stockholders could have been charged had such charter provision been omitted and in the case then before him he points out that the defendant had signed a writing reciting the intent of the subscribers to form a corporation to build and operate a hotel in California. This caution would warrant the inference that the Court felt that something more than the mere

55. 232 U. S. 221 (1914).

56. See p. 469 infra.

57. ARIz. Rev. Code (Struckmeyer, I928) § 579. 
holding of stock in the debtor corporation was necessary to justify the imposition of the statutory liability. Mr. Justice Holmes was willing to admit that its charter may empower a corporation to impose a liability upon a stockholder. Otherwise, so he felt, one seeking to hold a stockholder upon an obligation alleged to have been imposed by act of the corporation must show authority from the stockholder to the corporation. He was willing to assume that a corporation has no greater power in this regard merely because of a provision in the charter authorizing the doing of business in foreign states, especially if the charter makes no mention of a possible difference in laws as to stockholder liability. ${ }^{58}$ Here, too, one who seeks to hold a stockholder liable upon an obligation alleged to have been incurred by reason of the transaction of business by the corporation in a foreign state must show some authority to the corporation from the stockholder to impose the liability. Without such authority the statute of the foreign state imposing stockholder liability is not to be applied. And the grant of such authority cannot be predicated merely upon the fact that the corporation was acting within the scope of its charter powers in transacting local business within the foreign state. Something more than the transaction of such business is needed to subject the stockholder to the jurisdiction of the foreign state in respect to the imposition of individual liability.

Statements in Leyner Engineering Works v. Kempner ${ }^{59}$ agree with Mr. Justice Holmes. In that case the defendant was a stockholder in a Texas corporation which built a tunnel in Colorado. During such construction the plaintiff extended credit to the corporation for supplies and machinery, for which the corporation failed to pay. It had not qualified to do business in Colorado. Under the Colorado statute ${ }^{60}$ this failure made every officer, agent and stockholder jointly and severally personally liable on contracts of the corporation made within Colorado during the period the corporation was in default. According to Texas statute ${ }^{81}$ no stockholder in a Texas corporation was liable for its debts beyond the amount unpaid on his stock and no suit was to be instituted against a stockholder for the recovery of such unpaid amount until after judgment against the corporation and return of execution unsatisfied. The plaintiff sued defendant in Texas for the recovery of the amount due from the corporation, claiming that the statute of Colorado imposed liability. The defendant contended that enforcement of the Colorado statute would contravene the equalprotection-of-the-laws clause and the privileges and immunities clause.

58. 232 U. S. $221,233,234$ (rgr3).

59. I63 Fed. 605 (S. D. Tex. I908).

60. Colo. Gen. Laws I877, Ch. xix, \$§ 23-25.

6I. Tex. Stat. (Vernon, I928) Art. I395. 
The court held that the defendant's liability as stockholder was to be determined in accordance with the statute of Texas.

"What law fixes the liability of stockholders; that is, does the statute law of the state of incorporation fix and determine the liability of the shareholder, or is the liability to be determined and the stockholder charged by the enactments of every state in the Union in which the corporation may transact business? . . . That the law of the state in which the corporation is created, either in its constitutional provisions or legislative enactments, alone fixes and determines the liability of the shareholder, is beyond controversy. . .

"If the constitution to which a corporator has agreed does not provide for individual liability to creditors, he cannot be charged with individual liability anywhere." 62

There is no statement that the stockholder had knowledge of the corporation's transaction of business in Colorado; nor that he had knowledge at the time he acquired his stock of any intention to have the corporation transact business in Colorado. In Thomas $v$. Matthiessen the stockholder not only had knowledge of the intent to have the corporation build and operate a hotel in California, but in writing he expressed his desire that the corporation should do so. This matter of knowledge and expressed desire must be material. In fact, the Thomas case considers the defendant stockholder's knowledge and desire as evidence that the defendant had authorized the corporation to act as his agent in California - to make him a party to a contract made in California by the corporation with its creditor. However, the defendant stockholder had not in fact assented to the imposition of personal liability upon him. Quite the contrary. The existence of a principal-agent relationship between the defendant stockholder and the corporation is dubious. To argue that the defendant stockholder was bound because the corporation had his "authority" to impose a personal liability upon him is to beg the question. ${ }^{63}$

However this may be, why is it necessary to find a principal-agent relationship in order to justify California in imposing a liability upon the stockholder in the foreign corporation? In Thomas $v$. Matthiessen the stockholder defendant knows and assents to the transaction of business in that state by the corporation. As a stockholder he may benefit therefrom. He participates in the formation of a corporation to carry on a California business. His participation is a link in a chain of events that leads to the accrual of a claim in California. He becomes one cause of whatever act agents of the corporation do in its behalf in

62. 163 Fed. 605,608 , 610 (S. D. Tex. 1908).

63. See Note (1931) 44 HARv. L. Rev. 6r5, 617. 
California. He may not be liable under ordinary principles of agency for what the corporation does in California, but his participation in setting up the corporation is an ". . . element in the chain of those circumstances necessary to the result". ${ }^{64} \mathrm{He}$ becomes an author of harm suffered in California. Is it distasteful to the ideals of justice for California to impute liability to the non-resident stockholder ". . . if he be in fact the voluntary author of it though the sequence between his conduct and the damage would be too remote under ordinary principles"? ${ }^{65}$ In cases of tort liability like Young v. Masci ${ }^{66}$ and Scheer $v$. Rockne Motors Corp. ${ }^{67}$ such imputation would be upheld. Why not in Thomas v. Matthiessen? In torts the principles as to proximate causation that are enforced in cases wholly domestic to the forum are not necessarily to be enforced in tort cases involving conflict of laws. ${ }^{68}$ The distinction drawn in torts between cases involving conflict of laws and those that do not suggests that similar distinctions may be drawn in other fields of the law. Arizona by statute conferred upon the stockholders the privilege of doing business with limited liability not only within its borders but beyond. California, perhaps, could not have imposed liability upon stockholders for debts contracted in California in the course of interstate business. ${ }^{69}$ The interest of the United States in freedom of interstate commerce from local burdens might have overridden any local California interest. Nor could California have imposed the statutory liability for debts contracted outside of the state, certainly if not contracted incidentally to the course of California business. ${ }^{70}$ Such a statute would seem to be beyond its legislative competence. Nor could California have provided for personal liability for a debt arising out of a contract executed in California if that contract had been an isolated transaction on the part of a foreign corporation not doing a local business there. ${ }^{71}$ Any interest of California in having creditors paid their claims when incurred in the state would not suffice to outweigh the interest of Arizona in having members of its corporation immune from personal liability. But any interest of Arizona could reasonably be held outweighed by the facts that (I) the corporation was

64. Scheer v. Rockne Motors Corp., 68 F. (2d) 942, 944 (C. C. A. 2d, I934).

65. Ibid.

66. 289 U. S. 253 (1933).

67. 68 F. (2d) 942 (C. C. A. 2 d, 1934).

68. Cheatham, Internal Law Distinctions in the Conflict of Laws (1936) 2I CoRN. L. Q. 570,583 .

69. No case under the California statute seems to have involved a corporation engaged in interstate commerce.

70. Would not a statute permitting California to impose liability upon stockholders of a foreign corporation for debts incurred outside of the state and not contracted as an incident of business conducted in California be beyond the legislative competence of California?

7I. A question similar to that set forth in the preceding footnote could be pertinently raised here. 
formed to do business in California of a kind peculiarly local to that state, (2) such business was transacted in the state, (3) in the course whereof the debt was contracted, very likely to a California citizen and resident. The defendant may have received no profits, but it is not unreasonable to hold that the chance of profits from an enterprise so closely associated with California with the consent of the stockholder should travel with a liability for debts incurred in the course of that enterprise.

Suppose that the plaintiff had sued in California instead of New York. Under Pinney v. Nelson California could have enforced its statutory liability without violating due process. Suppose that the plaintiff had sued in Alizona. The Arizona court could properly have enforced the statutory liability. Of that we can be sure from Thomas $v$. Matthiessen. Suppose, however, that the Arizona court had taken the position that it should give effect to its own statutory declaration that stockholders in the Arizona corporation should be free from personal liability for any debt of the corporation. Would there have been an unconstitutional denial of full faith and credit? In the Thomas case the matter of full faith and credit seems not to have been raised, but because of California's numerous "contacts" the conclusion seems inescapable that the Federal Supreme Court would hold that any public policy of Arizona would have to yield to California's superior "governmental interest". ${ }^{72}$ The Court might well feel that a conflict of laws question should be converted into one of constitutional law so as to secure uniformity of decision among all state courts as to the circumstances under which liability could be enforced under the California statute. $^{73}$

Pinney $v$. Nelson is the weaker case in that the defendant had not so clearly expressed his desire to have corporate business transacted in California. However, the corporation was expressly chartered for the transaction of such business, such business (of a peculiarly local nature) was transacted in the state and the debt was incurred in the state. California again had significant "contacts". The holding would apply against any stockholder, not merely an original incorporator and subscriber to the stock. ${ }^{74}$ Perhaps it is material that the defendant was a California resident. ${ }^{75}$

In Leyner Engineering Works v. Kempner, Colorado had no similar "contacts". The debt was incurred in Colorado business, but the

72. The quoted phrase is borrowed from Alaska Packers Association v. Industrial Accident Commission, 294 U. S. 532 (I935).

73. As to this argument of expediency see Note (1939) 39 CoL. L. REv. I024.

74. See also Thomas v. Wentworth Hotel Co., I58 Cal. 275, IIo Pac. 942 (I9ro) ; Peck v. Noee, 154 Cal. 35I, 97 Pac. 865 (Ig08).

75. See Risdon Iron \& Locomotive Works v. Furness [1905] I K. B. 304, 315, aff'd [1906] I K. B. 49. 
corporation had not been incorporated particularly for that business. Indeed it was not licensed to do business in Colorado. No evidence shows that the defendant ever knew that such business was contemplated. The "contacts" between Colorado and the defendant seem insufficient to justify the imposition of liability upon the latter for debts incurred in the course of the Colorado business. This insufficiency is brought out when one considers the cases in the next section involving the problem of stockholder and other individual liability for obligations of a corporation that transacts business in a state other than that of incorporation without qualifying under the laws of the foreign state.

At any rate, it seems clear that merely because a state has permitted a foreign corporation to carry on a local business within its borders the state does not have jurisdiction to impose liability upon any stockholder, regardless of his citizenship or residence, for debts of the corporation, whether incurred in the course of that local business or not. There is one California case, to be sure, that seems to hold that the state would have jurisdiction to impose liability on any stockholder for debts of the corporation incurred in the local business in that state. ${ }^{76}$ However, Thomas v. Matthiessen reveals the necessity for some contacts between the stockholder and California other than the mere transaction of local business in the state to justify the application of the state constitutional and statutory provisions to a stockholder in a foreign corporation.

\section{Liabilities Consequent Upon Failure of Foreign Corpora- tion to Comply Wrth State Statute.}

Now we are concerned with cases in which state $X$ has granted a corporate charter and thereafter in $Y$ officers, directors, agents or stockholders-some or all-have engaged in commercial activities ostensibly in the name and on behalf of the corporation, but without compliance with statutes in $Y$ passed to regulate those intrastate activities of foreign corporations which constitute "doing business". Suppose that $A, B$ and $C$ are directors and officers as well as stockholders. Without observance of the requirements of the statutes of $Y$ they purport to do business in that state in the name and on behalf of the corporation. For obligations incurred in $Y$ apparently in the name of the corporation do they incur personal liability?

In Ryerson \& Son $v$. Shaw ${ }^{77}$ an Illinois statute required a foreign corporation before doing a local business to file certain documents and

76. Provident Gold Mining Co. v. Haynes, I73 Cal. 44, 159 Pac. I55 (1916). Cf. Boteler v. Conway, 13 Cal. App. (2d) 79,56 P. (2d) 587 (I936), 23 Cal. App. (2d) 35,72 P. (2d) 208 (I937).

77. 277 IIl. 524 , II5 N. E. 650 (I9I7). 
to appoint an attorney to receive service of process in Illinois. ${ }^{78}$ For failure to obey the statute a foreign corporation was liable to a fine and was disqualified from maintaining any action "upon any claim, legal or equitable, whether arising out of contract or tort in any court in this State". ${ }^{79}$ A Maine corporation had not qualified under the Illinois stalute, but did business in the state, in the course of which $P$ supplied goods and services ordered in the name and on behalf of the corporation. The Supreme Court of Illinois held that officers and directors might be held liable therefor on some theory of warranty of authority, saying that "a person who assumes to act as agent for a legally incompetent principal renders himself personally liable to the person with whom he deals unless such person knows of the want of authority". ${ }^{80}$ This reasoning is open to question. The creditor, $P$, had a right in contract against the corporation. On what ground, then, could liability be imposed upon the defendants? ${ }^{81}$

Whatever the answer, clearly liability was not imposed on the officers and directors as such. A state might have a statute, the court pointed out, providing that the failure of a foreign corporation to comply with the requirements for a license to transact a local business should render all officers, agents and stockholders personally liable on all contracts of the corporation made within the state during the period of default. Illinois had no such statute; "such a statute is much broader than the liability claimed in this case, because it includes stockholders and others having nothing to do with the particular business or contract out of which a canuse of action arises." $82 \quad P$, therefore, could not have held the stockholders in the Maine corporation to a personal liability in the absence of an express statute. "Participation" in the transaction out of which the cause of action arose would have had to be shown. ${ }^{83}$

There are a few cases in accord with Ryerson \& Son $v$. Shaw. ${ }^{84}$ But there are some contra, where the corporation is fined for doing business without qualifying under the statute, but no personal liability for obligations of the corporation is imposed on officers and directors even though they participated in carrying on the business. ${ }^{85}$ Even if no provision is made for punishing the corporation, and even though

78. Ill. Rev. Stat. (Hurd, I9I5-I6) c. 32, §67c.

79. Id., $\$ 67 \mathrm{~g}$.

80. 277 Ill. 524, 53I, II 5 N. E. 653 (I9I7).

81. In explanation of Ryerson \& Son v. Shaw see Critchfield \& Co. v. Armour, 228 IIl. App. 28, 4I (I923). See alsa Brown v. Sprague, 229 Ill. App. 338 (1923); but cf. RestATEMENT, AGENCY (1933) \& 332, comment $b$.

82. 277 IIl. 53 I, II 5 N. E. 653 (IgI7) (Italics added).

83. See The Class Journal v. Harlan, 2I5 Ill. App. 9 (Igrg).

84. Lasher v. Stimson, I45 Pa. 30, 23 Atl. 552 (r892), cited in Raff v. Isman, 235 Pa. 347, 35I, 84 Atl. 352, 353 (I912).

85. American Soap Co. v. Bogue, I14 Ohio St. I49, I50 N. E. 743 (I926) ; Martin Bros. v. Nettleton, 138 Wash. 102, 244 Pac. 386 (Ig26). 
it was formed abroad to carry on business in the state with the statutes of which it failed to comply, no liability has been imposed upon officers, directors or stockholders for obligations incurred ostensibly in behalf of the corporation. ${ }^{86}$ The rights of the plaintiff run only against the corporation.

Still another type of statute may expressly impose liability upon officers, agents or stockholders of a foreign corporation for corporate obligations if it carries on a local business within the state without complying with the statute regulating the admission of foreign corporations. For example, the Virginia Code required a foreign corporation doing business in the state to maintain an office therein and to appoint an agent to receive service of process. By Section II05 "the officers, agents and employees of any such company doing business in this State without complying with the provisions of the preceding section shall be personally liable to any resident of the State having a claim against such company. . . ." In Richmond Standard Steel Spike \& Iron Co. v. Dininny ${ }^{87}$ the legislature was held to have no power to impose liability for claims against the corporation upon officers, agents and employees who were citizens and residents of other states and had never been in the state aiding in carrying on the prohibited business.

"There are good reasons why the controlling officials of a foreign corporation who cause their company to carry on business in this State in violation of her laws should be made liable to her citizens for their claims against the company growing out of such business, if it could be done, although non-residents of the State; but there is no reason for making . . . liable the subordinate officers and the agents and employees of the company who did not reside in the State, and who were in no way responsible for their company's acts in this State." 88

The court did not discuss who would be "controlling" officers, or who would be "subordinate". It gave no hint as to whether actual exercise of a power of control would be necessary for the imposition of liability upon an officer or whether liability could be predicated upon the mere privilege of exercising control. Liability could be imposed only for a claim incurred to a Virginia resident in the course of the prohibited business. No further exposition is given as to what would constitute sufficient "contacts" with Virginia to constitute aiding in the carrying on of the prohibited business, but that some "contacts" were regarded as essential is certain. ${ }^{39}$ It is plain that if the Code had included stockholders with officers, agents and employees, liability for

86. Beal v. Childress, 92 Kan. 109, I39 Pac. II98 (I9I4).

87. 105 Va. 439, 53 S. E. 96 I (1905).

88. Id. at $44 \mathrm{I}, 53 \mathrm{~S}$. E. at $96 \mathrm{I}$ (I905) (Italics added).

89. See Goldsberry v. Carter, Ioo Va. 438, 4I S. E. 858 (Ig02). 
corporate obligations would not have been imposed on a stockholder merely because of his holding of stock. Some "contacts" between him and the carrying on of the prohibited business would have been necessary.

The statute of North Dakota ${ }^{90}$ imposing on officers, agents and stockholders of a foreign corporation unlawfully doing business in the state liability for any and all contracts made within the state by such corporation has been enforced against officers, ${ }^{91}$ but no case seems to have arisen in which enforcement has been sought against mere stockholders. Refusal to enforce liability under a similar Colorado statute has already been noted. ${ }^{.2}$

Statements occur from which one might conclude that the Tennessee courts impose upon stockholders of a foreign corporation failing to domesticate in the state personal liability for obligations incurred or performable in Tennessee on credit of the corporation. ${ }^{93}$ That conclusion would be inaccurate. According to a late case,

"The pertinent principle upon which individual or partnership liability rests for obligations created in a corporate name is nonrecognition of the corporate existence whenever the obligations sued on arise out of the doing of business in Tennessee without domesticating here. There being no corporation to be bound, those participating, whether stockholders, officers or other agents, in the doing of the business which gives rise to the demand, are held liable. . .

"It must be borne in mind that the prohibition of our statutes is against the doing of business in this State without domesticating here. It is a violation of this prohibition which results in individual liability. The corporate cloak does not protect the participating individuals from liability for these obligations which are incurred in the doing of business in Tennessee, unless the corporation is domesticated here." 94

Thus, Tennessee holds that stockholders in a foreign corporation doing a local business in the state without complying with the Tennessee statute are liable for corporate obligations incurred in the course of such business only if they have "participated". And a stockholder "participates" in Tennessee business if the corporation is chartered to exploit mineral

90. N. D. Rev. CoDe (I905) $\$ \$ 4695-4699$.

91. Chesley v. Soo Lignite Coal Co., I9 N. D. I8, I2I N. W. 73 (Ig09), semble.

92. Leyner Engineering Works v. Kempner, I63 Fed. 605 (S. D. Tex. I908). See pp. 467, 470 supra. Liability has been enforced under the Colorado statute against the incorporators, agents, officers and directors of a Delaware corporation. Keeler v. Union Trust Co., 84 Colo. 353, 270 Pac. 867 (I928).

93. See 2 BEALE, THE CoNFLICT OF LAWS (1935) \$ 179.28, and n. 2.

94. Campbell-Moss-Johnson, Inc. v. Lupton, 155 Tenn. 93, 95, 97, 290 S. W. 992, 993 (I927), petition for rehearing denied, I S. W. (2d) 783 (1927). (Italicization of "participating" in second paragraph added.) 
and timber resources in Tennessee and work is done in Tennessee pursuant to that purpose. For a claim accruing as a result of work done in the course of such development a stockholder incurs personal liability. ${ }^{95}$ It seems that a stockholder is a "participant" in Tennessee business also if he votes to have the foreign corporation, formed to work coal and iron lands in Tennessee, execute a mortgage on that land. ${ }^{90}$ Beyond this the Tennessee courts give no aid. Where stockholders have been held liable they have been spoken of as "participating", but the nature of their "participation" has not been set forth. ${ }^{97}$

At this point Towle $v$. Beistle ${ }^{98}$ merits discussion. In that case the defendants were stockholders in Acme Manufacturing Company, an Indiana corporation organized to do business in Indiana. It had engaged in business in Tennessee without observance of the Tennessee statute. $^{99}$ The corporate activities had been so extended to Tennessee without the "affirmative assistance, consent, or participation" of the defendants. The plaintiff sought to hold them liable on trade acceptances given and payable in Tennessee and arising from transactions entered into in behalf of the corporation in that state. The Appellate Court of Indiana affirmed judgment for the defendants, saying:

"The mere fact alone of ownership of the common capital stock by the appellees ... . is not sufficient to hold the appellees responsible for the obligations of the company . . .

"This brings us to a consideration of the question as to whether or not the amended complaint contains sufficient allegations to show a liability of the appellees for the obligations sued upon on the theory that they are participating stockholders in the transaction of the business of the offending corporation. Under the decisions if they are participating stockholders, they will be deemed to have consented to be bound. In the case before us there are no affirmative acts of participation alleged to have been done by the appellees. . . To participate in the sense necessary to bind the appellees herein it was necessary for them to do an affirmative act, to take part, to consent either affirmatively or in contemplation of law to be bound." 100

The Appellate Court refused to indulge in dicta as to what acts or failures to act might constitute "participation". ${ }^{101}$

95. Cunnyngham v. Shelby, I36 Tenn. 176, I88 S. W. I147 (1916).

96. See Equitable Trust Co. v. Central Trust Co., I45 Tenn. I48, I75, 239 S. W. I7I, I8I (I92I).

97. Neither of the Tennessee cases cited in notes 95 and 96 supra discuss at length the matter of "participation". Cf. London Guaranty \& Accident Co. v. Signal Mountain Coal Mining Co., I5 Tenn. App. 124 (1932).

98. 97 Ind. App. 24I, I86 N. E. 344 (I933).

99. Tenn. Laws I89I, c. I22, §§ I-4, as amended by Tenn. Laws I895, c. 8I, §§ I-3.

100. 97 Ind. App. 241, 247-249, I86 N. E. 344, 346 (I933) (Italics added).

ror. Ibid. One would infer that the Indiana court felt that it was deciding the case before it as a Tennessee court would have done. 
Suppose, however, that the Indiana court had found that under a Tennessee statute as construed by the Tennessee courts mere ownership of stock in the Acme Manufacturing Company under the circumstances of the case sufficed to make the owners liable for the corporate debts contracted in Tennessee. Such construction of the Tennessee statute might not have violated due process, had the corporation been formed in Indiana for the express purpose of engaging in an intrastate business in Tennessee. ${ }^{102}$ Nor would enforcement of the statute in Tennessee courts against stockholders, who had either subjected their persons to the jurisdiction of the Tennessee courts or had been residents of Tennessee at the time the corporate obligations were incurred, ${ }^{103}$ have offended the Fourteenth Amendment. Perhaps under these conditions the full faith and credit clause would require Indiana to allow suit in its courts to enforce the obligations arising under the Tennessee statute. ${ }^{104}$

The Arkansas court has also refused to impose liability upon stockholders of a Delaware corporation for debts of the corporation contracted in Tennessee while the corporation was doing business in the latter state without complying with the Tennessee statute. ${ }^{105}$ The court may have had a feeling that the liability which it assumed would have been imposed in Tennessee was "penal". However, the court did say that if a Tennessee statute had imposed the liability, it might have held that the stockholders were under a "contractual" liability enforceable in Arkansas. Perhaps the court felt that the full faith and credit clause would compel it to allow the enforcement of a liability arising under a Tennessee statute expressly making the stockholders liable for debts incurred in Tennessee by a foreign corporation doing business there without a license.

Going back to the assumption that under a Tennessee statute as construed by the courts of that state mere ownership of stock in the Acme Manufacturing Company sufficed to make the holders of the stock liable for corporate obligations contracted in Tennessee, the duty of Indiana to give full faith and credit to the statute would seem to turn on whether or not the doing of intrastate business in Tennessee sufficed to give that state sufficient "contact". Whether or not the application of the Tennessee statute by Tennessee to non-resident stockholders would in circumstances like those in Towle $v$. Beistle offend the due process clause would seem to turn also on that question.

I02. See Thomas v. Matthiessen, 232 U. S. 221 (1913). See pp. 457,463 supra.

103. This seems a warrantable conclusion from Pinney v. Nelson, I83 U. S. 144 (I90I). See pp. 465,470 supra.

I04. Thomas v. Matthiessen, 232 U. S. 221 (IgI3), semble. See pp. 457, 463 supra. 105. American Trust Co. v. Vandertuuk, I75 Ark. 728, I S. W. (2d) 41 (r927). 
The conclusion has already been reached ${ }^{106}$ that a state does not have jurisdiction under the Constitution to impose upon a non-resident stockholder in a foreign corporation personal liability for a debt of the corporation merely because the debt was incurred within the state in the course of local business. Something more is needed. The "something more"-the additional "contact"-may be citizenship or residence of the stockholder in the state. The requirement for the "something more" may be satisfied if the corporation was formed for the express purpose (set forth in the charter or articles of association) of doing business in the state which seeks to impose the individual, personal liability. Or the requirement may be satisfied if proof be made that the stockholder at the time he acquired his stock knew or had reason to know that the corporation was doing or would do a local business in that state. In no case was there any question of the propriety of the doing of the local business by the foreign corporation save in Leyner Engineering Works v. Kempner, ${ }^{107}$ and there no liability was held to fall upon the stockholder. If the power of a state to impose personal liability upon a stockholder in a foreign corporation licensed to do business within the state is limited in the manner indicated, must not the state be as narrowly limited in jurisdiction to impose individual liability for debts incurred in the name and on behalf of a foreign corporation in the course of a local business for the doing of which the corporation has not been licensed? How can the failure of the corporation to secure a license implement the jurisdiction of the state over a non-resident stockholder who has not participated in the doing of the local business? It is hard to see how this question can receive other than a negative answer. ${ }^{108}$

To recapitulate, the jurisdiction of a state to impose a liability upon a stockholder in a foreign corporation licensed to do a local business in the state is closely parallel to its jurisdiction to impose liability upon a stockholder in a foreign corporation doing a local business without a license. The stockholder liability seems limited to obligations incurred in the course of the local business within the state. In both situations the doing of the local business has not been regarded as sufficient to give the state jurisdiction to impose personal liability upon the non-resident stockholder. He must somehow "participate" by giving his personal assent to the conduct of the local business or by taking part therein as a "worker" of some sort. It may be that the power of

106. See p. 47I supra.

I07. I63 Fed. 605 (S. D. Tex. I908). See pp. 467,470 supra.

108. Cases dealing with tort liability are rare. When liability in tort has been imposed on a stockholder in an unlicensed foreign corporation, he has "participated" in the local business in the course of which the injury was caused to the plaintiff. Mandeville v. Courtright, 142 Fed. 97 (C. C. A. 3d, 1905). See also Rowden v. Daniell, 151 Mo. App. I5, 132 S. E. 23 (1910). 
the state over a resident shareholder is greater than over a non-resident. In short, although the point has been raised in only one case, ${ }^{109}$ the cases are in actual decision (whatever the professed reasoning) consistent with the theory that a state other than that of incorporation is under a duty to give full faith and credit to the immunity from personal liability granted a stockholder by the statute of the state of incorporation, unless some interest is shown in imposing personal liability that is superior to the interest of the state of incorporation in granting immunity from such liability. Granting that such a duty exists, the conclusion will be that the power of a state to "exclude" a foreign corporation from a local business turns on whether the state can show that some proper interest of its own is served by such "exclusion". It is difficult for a state to show such an interest when it extends the privilege of doing the same kind of a local business to corporations of its own creation, without limitation to number, which are formed subject to requirements similar to those to which the foreign corporation is subject under the law of the state of its creation.

\section{Exclusion of Foreign Corporations}

None of the cases considered in the preceding section involved a state of facts in which a state had sought to exclude foreign corporations entirely from local business and to give a monopoly thereof to domestic corporations. The cases dealt with situations in which a foreign corporation could have qualified to transact a local business, but failed to comply with a statute. Nevertheless local business was done in its name and on its behalf. The conclusion was reached that failure to comply with the statute did not prevent the state from imposing liability upon the corporation for obligations incurred in the course of local business. As to such the corporation was subject to the jurisdiction of the courts of the state. But the state, it was seen, did not have jurisdiction to impose liability upon mere stockholders as such.

The jurisdiction of the state would be no broader were there a statute to exclude foreign corporations entirely from local business. If in violation of such a statute a foreign corporation through agents were to transact local business, no doubt the corporation could be held liable in the courts of the state on causes of action arising out of the business it had been forbidden to transact. The state might refuse all legal effect to bargains made in the course of such business and deny any right of action thereon to persons bargaining with the corporation. The disposition, however, is to permit the enforcement against an unlicensed foreign corporation of bargains made by it in the course of

109. Leyner Engineering Works v. Kempner, 163 Fed. 605 (S. D. Tex. 1908). 
the prohibited business. ${ }^{110}$ The state might enjoin individuals from acting as agents within the state in behalf of the foreign corporation or might institute proceedings in the nature of quo warranto against the foreign corporation. Persons enjoined from acting as agents might, nevertheless, disobey the injunction and the foreign corporation might disregard a decree of ouster. Liabilities on obligations incurred in local business transacted in disregard of such judicial decrees would be no more extensive than before. The statute itself is an injunction in general terms and a decree against certain specified persons or in proceedings in the nature of quo warranto could hardly enlarge the jurisdiction of the state over persons outside.

What is the reality back of the principle that the state may impose liability upon the foreign corporation doing business in the state in violation of statute? The state does not have jurisdiction to impose liability for obligations incurred in the course of such business upon stockholders in the corporation as individuals merely because they are stockholders. It does have jurisdiction to impose liability upon them in their corporate capacity-in accord with the law of incorporation. But in the absence of special contacts between it and stockholders as individuals it cannot impose liability upon the latter in violation of the law of incorporation. To that extent a state is under a duty to give full faith and credit to a foreign corporation law or to a charter secured under such a statute.

In practice a foreign corporation is not going to persist in doing a local business if the state is constantly making life unpleasant for persons acting in the corporation's behalf. Somehow the corporation will challenge the validity of the statute that purports to authorize state officers to make life troublesome for its agents or employees. In certain cases the courts will feel that the state is justified in taking steps that will induce investors in a business enterprise to secure local incorporation. In Railway Express Agency v. Virginia, ${ }^{\text {111 }}$ for example, if we could imagine the Express Company as carrying on an intrastate business in disregard of the decision, the agents acting in the state for the corporation could be fined or imprisoned. But mere non-resident stockholders, taking no part in the Virginia business, could not be charged with personal liability for debts incurred in Virginia. Only in their corporate capacity - only in accord with the law of their incorporationcould liability be imposed upon them by Virginia for claims arising in the course of the Virginia business. Thus even when it is said that a corporation can be "excluded" from a state, one should remember that

ito. Restatement, Conflict of Laws (I934) §I79 and comment; 2 Beale, op. cit. sipra note 93 at $\$ \S I 79.24$ and 179.25 .

III. 282 U. S. 440 (193I). 
the state is not at liberty to disregard the law of incorporation completely. In imposing liability upon the stockholders the state has to follow the rule of limited liability laid down by that law unless some additional "contact" between it and the particular stockholder is established. The state will have to implement its policy of not allowing foreign corporations to transact domestic business of intrastate character by some other means.

The theory of the power of a state to "exclude" foreign corporations was formulated at a period prior to widespread recognition in this country of the corporate device as a useful and desirable form of associated enterprise-at a time when the desire to restrict the powers of corporations outside of the state of incorporation was strong. The history of the American law of corporations during the past century has been described as one of "judicial groping for a reconciliation between the practical position achieved by the corporation in society and a natural desire to confine the powers of these artificial creatures." 112 That attempt at harmonizing has attained a large degree of success. ${ }^{113}$ The time has come to abjure lip service to the theory of the power to "exclude" and to recognize that a state does have to give full faith and credit to such parts of the corporation law of a sister state as regulate the legal relations to third persons of members of a corporation organized under that law and that only when the state shows a sufficiently strong governmental interest will it be allowed to take such steps against individuals as will effectively dissuade them from acting within its territory in behalf of the foreign corporation.

I 12. Neirbo Co. v. Bethlehem Shipbuilding Corp., 308 U. S. I65, I69 (I939).

II3. Id. at I69 et seq. 